\title{
35. UPPER JURASSIC-LOWER CRETACEOUS PRIMITIVE ARENACEOUS FORAMINIFERA FROM DSDP SITES 259 AND 261, EASTERN INDIAN OCEAN
}

\author{
Helmut Bartenstein, Mobil Oil AG in Deutschland, D-3100 Celle, Germany
}

\section{INTRODUCTION}

Primitive one- and two-chambered representatives of the arenaceous foraminiferal genera Bathysiphon. Hyperammina, Kalamopsis, Hippocrepina, Proteonina, Lituotuba, Glomospira, Ammodiscus, and Sorosphaera are described and figured in this report.

These fossils are from the following samples: Samples 259-25-2, 26-28 cm; 259-26-2, 42-44 cm; 259-32, CC; 261-29, CC; 261-30, CC; 261-31, CC; 261-32, CC (I and II): $261-33-1,0-20 \mathrm{~cm}$ (above basalt).

The entirely arenaceous foraminiferal fauna at Site 259 Cores 18-33 (160-312 m) contain multichambered forms in addition to the one- and two-chambered varieties. The multichambered foraminifera will be described in a later paper. Arenaceous foraminifera are frequent in Core 18 (160-169.5 m), rare in Cores 19-29 (169.5-274 m), frequent in Cores 30-32 (274-302.5 m), and rare again in Core $33(302.5-312 \mathrm{~m})$. The arenaceous foraminifera from Site 259 described in this paper come chiefly from Core 32 .

The foraminiferal assemblages from Site 261 are much more diverse than those from Site 259. These assemblages contain numerous calcareous benthonic forams in addition to a fairly rich arenaceous fauna. The calcareous forams and the multichambered arenaceous species are described and figured in this volume by $\mathrm{K}$. Kuznetsova. The distribution of the one- and twochambered arenaceous foraminifera is shown in Figure 2 .

Based on calcareous nannoplankton, the cores from Site 261 were dated by F. Proto Decima (this volume) as follows:

Core 29, 30, top 31: Valanginian

Core 31, except top: Valanginian or Berriasian

Core 32: Tithonian/Kimmeridgian

Core 33: upper Oxfordian

The upper Oxfordian is characterized by the presence of Stephanolithion bigoti, Watznaueria manivitae, W. britannica, and Zygodiscus solillum. Based on multichambered arenaceous and calcareous benthonic foraminifera, K. Kuznetsova (this volume) dates the Site 261 Cores $29-31$ as Valanginian and Cores 32,33 as Lower Cretaceous/Upper Jurassic. Dinoflagellates at Site 261, Core 32 indicate a Kimmeridgian/?Tithonian age (Wiseman and Williams, this volume).

The cores from Site 259 are dated as follows:

Cores 25, 26, and 32 are lower Aptian based on dinoflagellates, and Cretaceous s.l. based on Radiolaria. Pollen and spores indicate an Aptian to Neocomian age for Cores 25 and 26 and a Neocomian age for Core 32. Nannoplankton are absent in these cores.

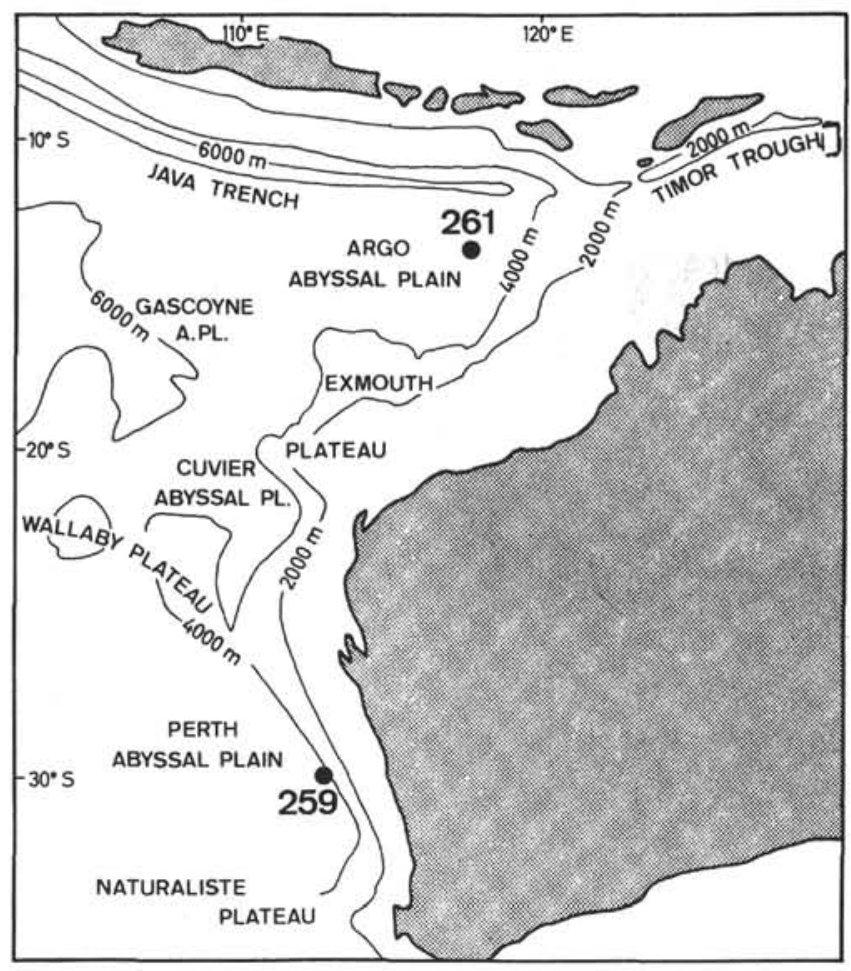

Figure 1. Location of Leg 27 Sites 259 and 261.

In this report only the primitive one- and twochambered uncoiled and coiled arenaceous foraminifera are described and figured. The multichambered serial and coiled arenaceous and calcareous foraminifera will be dealt with in a separate publication.

The figured specimens are deposited at the Museum of Natural History, Basel, Switzerland, under the numbers C 29935-30042.

\section{OBSERVATIONS ON THE FORAMINIFERAL ASSEMBLAGES}

Only the primitive arenaceous foraminifera are discussed in this paper. Based on lithofacies and faunas, the depth of deposition of the Upper Jurassic/Lower Cretaceous sediments at Site 261 increases upward in the section. Cores 31 to 33 , which contain calcareous and arenaceous foraminifera, together with calcite prisms of molluscs are deep-water sediments deposited above the lysocline. Cores 29 to 30 contain only arenaceous foraminifera, phosphatic fish scales, and siliceous sponge spicules, and were deposited below the lysocline. Only arenaceous foraminifera, siliceous sponge spicules, and some fish remains are present in Cores 18-33 from 


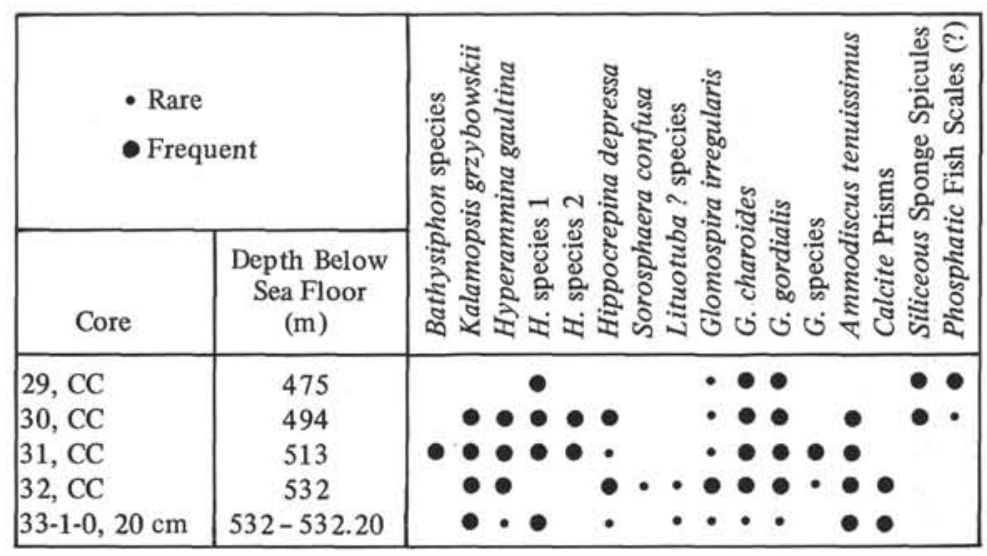

Figure 2. Distribution of primitive arenaceous foraminifera and some other fossil remains in Site 261, Cores 29-33.

Site 259 , which suggests that these sediments were also deposited below the lysocline.

The preservation of the foraminifera varies from excellent to very poor. The poorest preserved forams were observed from Core 29 of Site 261. The poor preservation of calcareous foraminifera in Cores 31-33 of Site 261 is the result of dissolution and/or recrystallization of calcite. The poor preservations make specific and even generic determinations difficult.

The foraminiferal assemblages are not typical for either Upper Jurassic or Lower Cretaceous. True index fossils are absent in all examined samples. The specific association of the arenaceous and calcareous foraminifera, influenced by corrosion and, possibly by mixing or redistribution of foraminifera of different ages, does not represent a normal, homogeneous fauna.

Based on nannoplankton determinations, Cores 29-33 Site 261 comprise Valanginian to upper Oxfordian. This is a time span of some $28 \mathrm{~m}$.y., represented by some 70 meters of section, within which only six samples were available for this report.

\section{FAUNAL COMPARISONS}

Upper Jurassic and Lower Cretaceous foraminifera from other Deep Sea Drilling sites in the Indian, Pacific, or Atlantic oceans are not presently available for comparison. Douglas (1971) described Lower Cretaceous benthonic foraminifera from the early Neocomian of Leg 6, Site 49 and figured 18 species; however, most of them are not typical index fossils. Systematic comparisons are based, therefore, on material in the literature, especially from the USA, Trinidad, Europe, and Africa.

Comparisons of the primitive arenaceous species with foraminifera from Sites 259 and 261 and from land-based sections are difficult. Some associations of the Leg 27 foraminifera are similar to associations in certain flysch deposits, e.g., the Bavarian flysch (Pflaumann, 1967). This raises the possibility that some of the Mesozoic Leg 27 sediments are flysch deposits. However, the Indian Ocean sediments are monotonous zeolite-bearing clays and claystones and do not possess the features characteristic of a flysch deposit.

\section{REMARKS ON THE STRATIGRAPHIC RANGES AND TAXONOMY OF THE PRIMITIVE ARENACEOUS FORAMINIFERA}

In the northern hemisphere, especially in the European flysch to which most of the literature refers, the foraminifera described herein range from uppermost Jurassic to older Tertiary or have somewhat more restricted distributions within this stratigraphic interval.

In my opinion, differences in test size (small, intermediate, giant); in wall material (smooth, coarse, fine grained, coarser grained); or in color (white, reddish-brown, or differently colored), do not justify the erection of new species or even genera. The differences might at best represent extreme variants. The distribution of these foraminifera is controlled by facies and they may therefore occur at different stratigraphic levels. Thus, when no decision could be made on a species name-which occurred in six cases-such forms were placed in open nomenclature.

\section{SYSTEMATICS}

(1) A group of arenaceous foraminifera whose test is wholly or in part arenaceous, free, single, or two-chambered (in one case-Sorosphaera-consisting of a colony of chambers), regular or irregular in size and arrangement; the two-chambered forms with proloculum and long undivided tubular second chamber. Included in this group are the genera Bathysiphon, Kalamopsis, Hyperammina, Hippocrepina, Proteonina, and Sorosphaera.

\section{Bathysiphon Sars, 1872 \\ BATHYSIPHON Sars, 1872 \\ Bathysiphon sp. \\ (Plate 1, Figures 1-4)}

Specimens with only fragmental chambers. Wall thick, composed of white cement, fine-grained, surface typically smooth, showing annular constrictions at irregular intervals; sponge spicules as wall components are never visible under higher enlargement.

Specimens of this kind may correspond to several species, mostly known from the European flysch facies with distribution in the Lower Cretaceous, Upper Cretaceous, and lower Tertiary. References and figures are given by:

Pflaumann (1967, pl. 2, fig. 1-3) as Dendrophryopsis communis and D. subalpina Pflaumann (both n. sp.?), and as Nothia grilli Pflaumann (n. sp. ?) from the Campanian in Bavaria, southern Germany. 
Hanzlikova (1966, p. 98, pl. 1, fig. 2-5) as Bathysiphon? brosgei Tappan, 1957, from the Moravian Albian.

Hanzlikova (1969, p. 18-19, pl. 1, fig. 1-4) as Bathysiphon vitta Nauss, 1947; B. taurinensis Sacco, 1896; and B. nodosariaformis Subbotina, 1950; from the Moravian Maestrichtian, Czechoslovakia Neagu (1970, p. 32, pl. 1, fig. 3, 4) as Bathysiphon brosgei Tappan, 1957, from the Rumanian Turonian and Campanian.

Neagu (1972, p. 190, pl. 1, fig. 8, 9) as Bathysiphon? brosgei Tappan,

1957, from the Rumanian Aptian.

From the American Arctic Lower Cretaceous, references and figures are given by:

Tappan (1962, p. 128, pl. 29, fig. 1-8) as Bathysiphon brosgei Tappan, 1957, and as B. vita Nauss, 1947.

Chamney (1969, p. 11-12, pl. 1, fig. 1-4) as Bathysiphon scintillata $\mathrm{n}$. sp. and as B. granulocoelia n. sp.

There is a distinct possibility that Bathysiphon sp., Hyperammina gaultina Dam, Hyperammina sp. 1 and 2, and Kalamopsis grzybowskii (Dylazanka) of the here investigated fauna are closely related. Additional studies on material from other parts of the world are needed to solve this problem.

\section{KALAMOPSIS Folin, 1883}

\section{Kalamopsis grzybowskii (Dylazanka)}

(Plate 1, Figures 31-34; Plate 2, Figures 27-35)

1923 Hyperammina Grzybowskii n. sp., Dylazanka, Rocz. Polsk. Tow. Geol., Krakow, v. 1, p. 65. Upper Cretaceous, Poland.

1967 Kalamopsis grzybowskii (Dylazanka), Pflaumann, Geol. Rundschau., v. 56, p. 209, pl. 2, fig. 3. Campanian, Bavaria.

1969 Kalamopsis grzybowskii (Dylazanka), Gruen, Rocz. Polsk. Tow. Geol., Krakow, v. 39, p. 308, pl. 61, fig. 1-8. Maestrichtian, Austria.

1970 Kalamopsis grzybowskii (Dylazanka), Neagu, Inst. Géol., Bucarest, Mém., v. 12, p. 32, pl. 1, fig.2. Campanian, Rumania

1972 Kalamopsis grzybowskii (Dylazanka), Neagu, Rocz. Polsk. Tow. Geol., Krakow, v. 42, p. 10, pl. 1, fig. 1-3. Vraconian to Cenomanian, Rumania.

Test simple, tubular, usually compressed, tubes showing annular constrictions at irregular intervals, but no subdivision into chambers Test finely cemented, white colored, surface smooth. Chambers frequently longitudinally compressed.

The specimens concerned may pass into the genus Hyperammina with transitional forms to Hyperammina gaultina Dam.

\section{HYPERAMMINA Brady, 1878}

\section{Hyperammina gaultina Dam}

(Plate 1, Figures 5-30, 35, 36; Plate 2, Figures 1-4)

1950 Hyperammina gaultina n. sp., Dam, Mém. Soc. Géol. France, Mém. 63, p. 5, pl. 1, fig. 2. Albian, The Netherlands and Germany.

1960 Hyperammina elongata Brady, Jovcheva, and Trifonova, Ann. Dir. Gén. Rech. Géol., Sofia, v. 11, p. 173, pl. 3, fig. 2. Berriasien. Bulgaria.

1963 Bathysiphon sp., Crespin, Bur. Min. Res. Geol. Geophys. Australia, Bull. 66, p. 19, pl. 1, fig. 1. Albian, Australia.

1963 Hyperammina sp. A, Crespin, Bur. Min. Res. Geol. Geophys. Australia, Bull. 66, p. 23, pl. 2, fig. 1. Aptian and Albian, Australia.

1966 Hyperammina gaultina ten Dam, Hanzlikova, Acta Mus. Moraviae, L I, p. 100, pl. 1, fig. 1. Albian, Moravia.

1966 Hyperammina gaultina Dam, Bartenstein, Bettenstaedt, and Bolli, Ecolog. Geol. Helv., v. 59, p. 137, pl. 1, fig. 6-13. Barremian, Trinidad, W.I.

1970 Bathysiphon dubius (White), Neagu, Inst. Géol., Bucarest, Mém., v. 12, p. 32, pl. 1, fig. 2. Campanian, Rumania.

1972 Hyperammina gaultina ten Dam, Neagu, Rocz. Polsk. Tow. Geol., Krakow, v. 42, p. 8, pl. 2, fig. 2. Vraconian to Lower Cenomanian, Rumania.

1972 Hyperammina gaultina Dam, Neagu, Rev. Espan. Micropaleontol., v. 4 , p. 190 , pl. 1, fig. 14-16. Hauterivian and Aptian, Rumania.

1973 Rhizammina? indivisa Brady, Maync, Initial Reports of the Deep Sea Drilling Project, Washington (U.S. Government Printing Office) v. 13, p. 1081, pl. 1, fig. 1, 2. (non Rhizammina indivisa) Barremian to Albian, offshore Portugal.

Test simple, tubular, usually compressed, wall finely agglutinated with white cement, mostly smooth. The specimens show an irregular growth with relatively slender tests (Plate 1, Figures 12-14, 17, 19-21, 26-30) or are extremely large (Plate 1, Figures 24, 25, 35, 36; Plate 2 ,
Figures 1,2), in which case they are comparable to tests of Bathysiphon as figured on Plate 1, Figures 1 and 3.

A review of the pertinent literature reveals that it is not always possible to distinguish the widely distributed Recent species Rhizammina indivisa Brady, 1884 from fossil species like Hyperammina gaultina Dam. References on Rhizammina indivisa are found in the following publications:

Jovcheva and Trifonova, 1960. Ann. Dir. Gén. Rech. Géol., v. 11, p. 173, pl. 3, fig. 1. Tithonian and Berriasian, Bulgaria.

Bartenstein, 1965. Senckb. Lethai., v. 46, p. 343. Lower Cretaceous, Germany.

Geroch, 1966. Rocz. Polsk. Tow. Geol., Krakow, v. 36, p. 434, pl. 6 , fig. 1-7. Tithonian to Cenomanian, Poland.

Maync, 1973. see above-mentioned synonymy. Barremian to Albian, offshore Portugal.

\section{Hyperammina sp. 1 \\ (Plate 2, Figures 5-14)}

1963 Hyperammina sp. B and C, Crespin, Bur. Min. Res. Geol. Geoph. Australia, Bull. 66, p. 23, pl. 2, fig. 2-4. Aptian (and Albian ?), Australia.

1970 Hyperammina gaultina Dam, Neagu, Inst. Géol., Bucarest, Mém., v. 12, p. 33, pl. 1, fig. 8. Turonian to lower Maestrichtian, Rumania.

Extremely slender compressed tubes, walls fine grained, with white cement. The specimens may be related to Hyperammina gaultina.

\section{Hyperammina sp. 2}

(Plate 2, Figures 15-22)

1966 Hyperammina gaultina Dam, Geroch, Rocz. Polsk. Tow. Geol., Krakow, v. 36, p. 435, pl. 6, fig. 14-18. Barremian to Cenomanian, Poland.

1966 Hormosina ovulum crassa n. ssp., Geroch, Rocz. Polsk. Tow. Geol., Krakow, v. 36, p. 439, 463, pl. 6, fig. 19-26. (Non pl. 7, fig 21-23) Barremian to Cenomanian, Poland.

Initial chambers (Proloculi) of Hyperammina, possibly of Hyperammina gaultina, consisting of fine-grained walls with white cement and mostly smooth surface. Small chambers (Plate 2, Figures 15-20) alternate with large chambers (Plate 2, Figures 21-22) without any possibility of specific distinctions.

\section{HIPPOCREPINA Parker, 1870 \\ Hippocrepina depressa Vasicek (Plate 2, Figures 23-26)}

1947 Hippocrepina depressa, Vasicek, Vest. Stat. Geol. Ustav, v. 22, p. 243, pl. 1, fig. 1, 2. Aptian to Albian, Moravia.

1959 Hippocrepina depressa Vasicek, Geroch, Palaeont. Z., v. 33, p. 114, pl. 12, fig. 15, 16. Barremian and Aptian, Poland.

1966 Hyperamminoides depressa (Vasicek), Hanzlikova, Acta Mus. Moraviae, v. L I, p. 100, pl. 2, fig. 6, 7. Albian, Moravia.

1966 Hippocrepina depressa Vasicek, Geroch, Rocz. Polsk. Tow. Geol., Krakow, v. 36, p. 435, 462, pl. 6, fig. 3, 8, 10-13. Hauterivian to Cenomanian, Poland.

1967 Kalamopsis discreta (Friedberg), Pflaumann, Geol. Rundschau., v. 56, p. 209 , pl. 2, fig. 2. Campanian, Bavaria.

1972 Hippocrepina depressa Vasicek, Neagu, Rocz. Polsk. Tow. Geol., Krakow, v. 42 , p. 8 , pl. 1, fig. 4. Vraconian to Cenomanian, Rumania.

1972 Hippocrepina depressa Vasicek, Neagu, Rev. Espan. Micropaleontol., v. 4, p. 190, pl. 1, fig. 10-13. Hauterivian to Barremian, Rumania.

1972 Hippocrepina depressa Vasicek, Gruen et al., Jahrb. Geol. B.-A., Wien, v. 115, p. 138, pl. 5, fig. 1-5. Albian, Austria.

The species is characterized by small, longitudinally compressed, high conical tubes with annular constrictions at irregular intervals; surface very smooth and bright, transparent.

\section{PROTEONINA Williamson, 1858}

The available material consists of only two specimens. Therefore, the genus name Proteonina is used instead of Reophax Montfort, 1808, in synonymy of which many authors place the genus Proteonina.

\section{Proteonina sp.}

\section{(Plate 2, Figures 36, 37)}

Test free, elongate, with one chamber, slightly compressed (Plate 2 , Figure 37 ), flask-like with finely arenaceous, relatively thick wall, 
white cement, surface smooth. Aperture terminal, a simple rounded opening (Figure 37); one specimen with two apertures (Figure 36). These two are the only Proteonina specimens present in the examined material.

This form may correspond to several published species, but with the poor material at hand, an assignment to one of them is difficult. References and figures are given by:

Crespin (1953, p. 28, pl. 5, fig. 1; 1963, p. 22, pl. 1, fig. 19-20) as Pelosina lagenoides Crespin, 1953, from the Albian in Australia.

Tappan (1962, p. 129) as Saccammina lathrami Tappan, 1960, (pars: pl. 29, fig. 11) and as Hyperamminoides barksdalei Tappan, 1957 (pars: pl. 2, fig. 21, 24) from the Arctic Albian.

Gruen (1970, p. 97, pl. 4, fig. 5-8) as Reophax elongatus Grzybowski, 1898, from the Upper Cretaceous and Paleocene in Austria.

\section{SOROSPHAERA Brady, 1879 \\ Sorosphaera confusa Brady \\ (Plate 3, Figure 18)}

1879 Sorosphaera confusa, Brady, Quart. J. Micr. Sci., n. Ser., v. 19, p. 28, pl. 4, fig. 18, 19. Recent, North Atlantic.

1972 Sorosphaera sp., Neagu, Rev. Espan. Micropaleontol., v. 4, p. 190, pl. 1, fig. 34-36. Barremian, Rumania.

1972 Sorosphaera confusa Brady, Hofker sen., Primitive Agglut.

foram., p. 71, pl. 22, fig. 1-8. Recent, Atlantic and Pacific, depths from 599 to about 4500 meters.

Test a cluster of subglobular chambers; where in contact with each other chamber surfaces appear flattened. Wall slightly roughened, cement white. No definite apertures visible.

The single test available from Site 261 shows the same shape and growth features as do Recent specimens but is more slender in diameter. According to Galloway (1933, p. 65) the Recent monotypic species occurs in deep, cold water between 443 and 3690 meters and has a colony diameter of up to $4.5 \mathrm{~mm}$.

Neagu reports from the Rumanian Barremian a similar form as Sorosphaera sp. It has a glomerate test with spherical to oval chambers, irregular in arrangement.

(2) A group of arenaceous foraminifera whose test consists of arenaceous material with much cement, free, two chambered, with proloculum and a second coiled chamber, regularly or irregularly coiled, in one case-Lituotuba? - partially uncoiled. Included in this group are the genera Lituotuba?, Glomospira, and Ammodiscus.

\section{LITUOTUBA Rhumbler, 1895}

\section{Lituotuba? sp.}

(Plate 2, Figures 38-40)

The available material consists of only three broken specimens, showing proloculum and one to two consecutive chambers. This is not sufficient for a specific determination. It appears that any relationship to the characteristic genus Rothina Hanzlikova, 1966, from the Eastern European Albian, can be excluded. The Site 261 specimens diffèr from it in the arrangement of proloculum and following chambers resp. tube.

The three tests also do not provide any indication whether the initial wall was calcareous or arenaceous. If it was calcareous, with later secondary recrystallization and silicification, the specimens may also belong to the families Ophthalmidiidae or Miliolidae showing their characteristic proloculi with following first stages of chambers.

Nodophthalmidium butellum Bartenstein and Brand (1951, p. 279, pl. 4, fig. 92), redescribed by Michael $(1967$, p. 33, pl. 10, fig. 12, 13) from the northwest German upper Valanginian through lower Barremian may be cited as an example for such a possibility.

Both families mentioned contain species with arenaceous or siliceous tests.

\section{GLOMOSPIRA Rzehak, 1885}

Glomospira irregularis (Grzybowski)

(Plate 2, Figures 41-44; Plate 3, Figure 19)

1898 Ammodiscus irregularis, Grzybowski, Rocz. Akad. Um. mat.przyr. wydz., Krakow, v. 33, p. 285, pl. 11, fig. 2, 3. Oligocene, Poland.

1960 Glomospira irregularis (Grzybowski), Geroch, Inst. Geol., Warszawa, Bull. 153, p. 47, 126, pl. 4, fig. 9, 10. Paleogene, Poland.
1966 Glomospira irregularis (Grzybowski), Hanzlikova, Acta Mus. Moraviae, v. LI, p. 102, pl. 2, fig. 3, 4. Albian, Moravia (persisting through Paleogene).

1966 Glomospira irregularis (Grzybowski), Geroch, Rocz. Polsk. Tow. Geol., Krakow, v. 36, p. 470, pl. 8, fig. 11, 12. Albian, Poland.

1969 Glomospira irregularis (Grzybowski), Hanzlikova, Sborn. Geol. VED, Paleontol., v. 11, p. 19, pl. 1, fig. 7. Maestrichtian, Moravia.

1969 Glomospira irregularis (Grzybowski), Gruen, Rocz. Tow. Geol., Krakow, v. 39 , p. 313 , pl. 65 , fig. 5. Maestrichtian, Austria (complete list of synonyms).

1970 Glomospira irregularis (Grzybowski), Neagu, Inst. Géol., Bucarest, Mèm., v. 12, p. 34, pl. 1, fig. 11. Cenomanian to Campanian, Rumania.

1972 Glomospira irregularis (Grzybowski), Neagu, Rocz. Polsk. Tow. Geol., Krakow, v. 42, p. 9, pl. 2, fig. 11. Vraconian to Cenomanian, Rumania.

The tubes are irregularly coiling without any system in contrast to G. charoides (horizontal coiling throughout) or G. gordialis (with trochospiral early whorls, later whorls with inclined planes of coiling, final whorl coiled around the early ones). Wall finely arenaceous, surface smooth, sometimes rough.

\section{Glomospira charoides (Jones and Parker) \\ (Plate 2, Figures 45-50)}

1860 Trochammina squamata var. charoides $\mathrm{n}$. var., Jones and Parker, Quart. J. Geol. Soc., London, v. 16, p. 304. Recent, North Atlantic.

1966 Glomospira charoides (Jones and Parker), Hanzlikova, Acta Mus. Moraviae, v. LI, p. 101, pl. 1, fig. 6. Albian, Moravia.

1967 Glomospira charoides (Jones and Parker), Michael, Palaeontogr., Suppl., p. 23, pl. 1, fig. 8. Lower Cretaceous, Germany.

1969 Glomospira charoides (Jones and Parker), Gruen, Rocz. Polsk. Tow. Geol., Krakow, v. 39, p. 318. Table 1, pl. 66, fig. 1-4. Maestrichtian to Eocene, Austria.

1972 Glomospira charoides (Jones and Parker), Neagu, Rocz, Polsk. Tow. Geol., Krakow, v. 42, p. 9, pl. 2, fig. 6-10. Vraconian to Cenomanian, Rumania.

1972 Glomospira charoides (Jones and Parker), Neagu, Rev. Espan. Micropaleontol., v. 4, p. 192, pl. 1, fig. 32. Hauterivian and Barremian, Rumania.

1973 Glomospira charoides (Jones and Parker), Maync, Initial Reports of the Deep Sea Drilling Project, v. 13, Washington (U.S. Government Printing Office) p. 1082, pl. 1, fig. 6, 7. Barremian to Albian, offshore Portugal.

The test is fairly regular with the tube coiling more or less trochospiral.

\section{Glomospira gordialis (Jones and Parker)}

(Plate 2, Figures 51-54; Plate 3, Figures 1-3)

1860 Trochammina squamata var. gordialis n. var., Jones and Parker, Quart. J. Geol. Soc., London, v. 16, p. 304. Recent, North Atlantic.

1967 Glomospira gordialis (Jones and Parker), Michael, Palaeontogr., Suppl. p. 23, pl. 11, fig. 13. Lower Cretaceous, Germany.

1969 Glomispira gordialis (Jones and Parker), Gruen, Rocz. Polsk. Tow. geol.. Krakow. v. 39. p. 313. Maestrichtian to Eocene, Austria.

1970 Glomospira gordialis (Jones and Parker), Neagu, Inst. Géol., Bucarest, Mém., v. 12, p. 34, pl. 1, fig. 12. Turonian to Lower Maestrichtian, Rumania.

1972 Glomospira gordialis (Jones and Parker), Neagu, Rocz. Polsk. Tow. Geol., Krakow, v. 42, p. 9, pl. 2, fig. 14, 15. Vraconian to Cenomanian, Rumania.

1972 Glomospira gordialis (Jones and Parker), Neagu, Rev. Espan. Micropaleontol., v. 4, p. 191. pl. 1, fig. 33; pl. 8, fig. 14, 15. Hauterivian and Aptian, Rumania.

1973 Glomospira gordialis (Jones and Parker), Maync, Initial Reports of the Deep Sea Drilling Project, v. 13, Washington (U.S. Government Printing Office) p. 1082, pl. 1, fig. 8. Barremian, offshore Portugal.

Irregular trochospiral coiling of the early whorls, later inclined planes of coiling, final whorl coiled around the early ones. No horizontal planes of coiling as in $G$. charoides. Wall finely arenaceous, surface mostly smooth. 
Glomospira sp.

(Plate 3, Figures 4-6)

1967 Glomospira and Ammodiscus, Michael, Palaeontogr., Suppl., v. 12 , p. 14 , draw. 6 .

No specific determination is possible; the specimens may belong to the variability of $G$. gordialis. Its distribution is the same. Michael (1967) discusses the problem and the difficulty in separating the genera Glomospira and Ammodiscus.

\section{AMMODISCUS Reuss, 1861}

Ammodiscus tenuissimus (Guembel) (Plate 3, Figures 7-13)

1862 Spirillina tenuissima n. sp., Guembel, Wuerttemb. Natl. Jahreb., Jg. 18, p. 214, pl. 13, fig. 2. Upper Jurassic, Germany.

1967 Ammodiscus tenuissimus (Guembel), Michael, Palaeontogr., Suppl., v. 12, p. 22, pl. 1, fig. 13. Lower Cretaceous, Germany.

1969 Ammodiscus tenuissimus (Guembel), Gruen, Rocz. Polsk. Tow. Geol., Krakow, v. 39, p. 312. Maestrichtian, Austria (complete list of synonyms).

1972 Ammodiscus tenuissimus (Guembel), Neagu, Rev. Espan. Micropaleontol., v. 4, p. 191, pl. 1, fig. 19-20. Barremian to.Aptian, Rumania.

The specimens are slender and extremely flat. Because of this, the tests are sometimes transparent.

Ammodiscus rotalarius Loeblich and Tappan, 1962 (p. 131, pars: fig.

6,8 ), seems to be closely related to $A$. tenuissimus. -Albian, Alaska.

\section{Ammodiscus incertus (Orbigny)}

(Plate 3, Figures 14-17)

1839 Operculina incerta, Orbigny, Hist. Phys. Pol. Nat. Cuba, p. 49, pl. 6 , fig. 16, 17. Recent, off Cuba.

1962 Ammodiscus cretaceus (Reuss), Tappan, U.S. Geol. Surv. Prof. Paper 236-C, p. 130, pl. 30, fig. 1, 2. Senonian, Alaska.

1967 Ammodiscus incertus (Orbigny), Michael, Palaeontogr., Suppl., v. 12, p. 21, pl. 1, fig. 12. Middle Barremian, Germany,

1969 Ammodiscus cretaceus (Reuss), Hanzlikova, Sborn. Geol. VED, v. 11, p. 19, pl. 1, fig. 5. Maestrichtian, Moravia.

1970 Ammodiscus cretaceus (Reuss), Neagu, Inst. Géol., Bucarest, Mém., v. 12, p. 33, pl. 2, fig. 1. Turonian to Lower Maestrichtian, Rumania.

1972 Ammodiscus cretaceus (Reuss), Neagu, Rocz. Polsk. Tow. Geol., Krakow, v. 42, p. 9, pl. 2, fig. 12. Vraconian to Cenomanian, Rumania.

Ammodiscus incertus differs from Ammodiscus gaultinus Berthelin, 1880, in its more regular coiling (see Maync, 1973, p. 108). The tests show radiate constrictions.

Ammodiscus siliceus (Terquem, 1862) may belong in synonymy with A. cretaceus: see the description by Gruen, 1969, p. 311, pl. 65, fig. 2-3. Maestrichtian, Austria.

\section{ACKNOWLEDGMENTS}

Gratitude is expressed to H. M. Bolli, Geology Department, Swiss Federal Institute of Technology, Zurich. As Leg 27 paleontologist, he collected the samples onboard ship, prepared the here published material, and made it available to the author. He also read the manuscript and made suggestions for its integration within the framework of the other Leg 27 paleontological reports dealing with Upper Jurassic-Lower Cretaceous faunas.

The author is also indebted to his friend, Heinz J. Oertli (Société Nationale des Pétroles d'Aquitaine, Pau), for providing the SEM photographs of Plates 1-3, and to Walter J. Schmidt, Vienna, for his advice on translating the German text.

\section{REFERENCES}

Bartenstein, H., 1965. Taxionomische Revision und Nomenklator zu Franz E. Hecht "Standard-Gliederung der Nordwest-deutschen Unterkreide nach Foraminiferen" (1938): Senckenb. Lethaia, v. 46, p. 327.
Bartenstein, H. and Bettenstaedt, F., 1962. Marine Unterkreide (Boreal und Tethys). In Leitfossilien der mikropalaeontologie: Berlin (Borntraeger).

Bartenstein, H. and Brand, E., 1951. Mikropaläontologische Untersuchungen zur Strabegraphie des nordwestdeutschen Valendis: Senckenb. Naturf. ges. Abhandl., no. 485, p. 239.

Bartenstein, H. and Kaever, M., 1973. Die Unterkreide von Helgoland und ihre mikropalaeontologische Gliederung: Senckenb. Lethaia, v. 54, p. 207.

Bartenstein, H., Bettenstaedt, F., and Bolli, H. M., 1957. Die Foraminiferen der Unterkreide von Trinidad, B.W.I. No. 1: Ecolog. Geol. Helv., v. 50, p. 5.

1966. Die Foraminiferen der Unterkreide von Trinidad, B.W.I. No. 2: Ecolog. Geol. Helv., v. 59, p. 131. 1973. Die Foraminiferen der Unterkreide von Trinidad, B.W.I. No. 3: Ecolog. Geol. Helv., v. 66, p. 389.

Bartenstein, H., Bettenstaedt, F., and Kovatcheva, T., 1971. Foraminiferen des bulgarischen Barreme: Neues. Jahrb. Geol. Palaeontol. Abhandl., v. 139, p. 125.

Beckmann, J. P., 1972. The foraminifera and some associated microfossils of Sites 135 to 144. In Hayes, D. E., et al., Initial Reports of the Deep Sea Drilling Project, Volume 14: Washington (U.S. Government Printing Office), p. 389.

Bukry, D., Douglas, R. G., Kling, S. A., and Krasheninnikov, V., 1971. Planktonic microfossil biostratigraphy of the northwestern Pacific Ocean. In Fischer, A. G., Heezan, B. C., et al., Initial Reports of the Deep Sea Drilling Project, Volume 6: Washington (U.S. Government Printing Office), p. 1253.

Crespin, I., 1963. Lower Cretaceous arenaceous foraminifera of Australia: Bur. Min. Res. Geol. Geoph. Australia, Bull. v. 66, p. 1.

Douglas, R. G., 1971. Cretaceous foraminifera from the northwestern Pacific Ocean: Leg 6, Deep Sea Drilling Project. In Fischer, A. G., Heezan, B. C., et al., Initial Reports of the Deep Sea Drilling Project, Volume 6: Washington (U.S. Government Printing Office), p. 1027.

Faupl, P., Gruen, W. et al., 1970. Zur Typisierung der Sieveringer Schichten im Flysch des Wienerwaldes: Jahrb. Geol., B.-A. v. 113, p. 73.

Galloway, J. J., 1933. A Manual of foraminifera: James Furman Kemp Memorial Series Publication no. 1.

Geroch, S., 1959. Stratigraphic significance of arenaceous foraminifera in the Carpathian flysch: Palaeontol. Z., v. 33, p. 113.

1966. Lower Cretaceous small foraminifera of the Silesian series, Polish Carpathians: Ann. Soc. Géol. Pologne, v. 36 , p. 413.

Gruen, W., 1969. Flysch microfauna of the Hagenbach Valley (northern Vienna Woods), Austria: Ann. Soc. Géol. Pologne, v. 39 , p. 305.

Gruen, W., Lauer, G., Niedermayr, G., and Schnabel, W., 1964. Die Kreide-Tertiaer-Grenze im Wienerwaldflysch bei Hochstrass (Niederoesterreich): Verhandl. Geol. Bundesanst., p. 226.

Gruen, W., Kittler, G. et al., 1972. Studien in der Unterkreide des Wienerwaldes: Jahrb. Geol. B.-A., v. 115, p. 103.

Hanzlikova, E., 1966. Die Foraminiferen der Lhoty-Schichten: Acta Mus. Moraviae, v. 51, p. 95.

1969. The foraminifera of the Frýdek Formation (Senonian): Sbornik Geol. Ved. Paleontol., v. 11, p. 7.

Hofker, J., 1972. Primitive agglutinated foraminifera: Leiden (Brill).

Jovcheva, P. and Trifonova, E., 1960. Microfauna of the Tithonian-Valangian in North-West Bulgaria: Ann. Dir. Gén. Rech. Géol., v. 11, p. 161.

Maync, W., 1973. Lower Cretaceous foraminiferal fauna from Gorringe Bank, eastern North Atlantic. In Ryan, W. B. F., 
Hsu, K. J., et al., Initial Reports of the Deep Sea Drilling Project, Volume 13: Washington (U.S. Government Printing Office), p. 1075.

Michael, E., 1967. Die Mikrofauna des nordwestdeutschen Barreme. Teil I: Die Foraminiferen des nordwestdeutschen Barreme: Palaeontogr., Suppl., v. 12, p. 1-176.

Mihailova-Jovcheva, P., 1965. Mikrofaunistische Untersuchungen im Tithon und Valendis des mittleren Nordbulgarien: Inst. Sci. Rech. Géol. Dir. Gén. Géol. Bull., v. 2, p. 61 .

Neagu, T., 1970. Micropaleontological and stratigraphical study of the Upper Cretaceous deposits between the upper valleys of the Buzau and Riul Negru Rivers (eastern Carpathians): Inst. Géol. Bucarest, Mém., v. 12, p. 1. 1972a. Cenomanian benthonic foraminifera in the southern part of the eastern Carpathians (Romania): Ann. Soc. Géol. Pologne, v. 42, p. 3.

1972b. The Eo-Cretaceous foraminiferal fauna from the area between the Ialonitza and Prahova Valleys (eastern Carpathians): Rev. Espan. Micropaleontol., v. 4, p. 181.

Pflaumann, U., 1967. Zur Oekologie des bayerischen Flysches auf Grund der Mikrofossilfuehrung: Geol. Rundschau,v. 56 , p. 200.

Tappan, H., 1955. Foraminifera from the Arctic slope of Alaska. Part 2, Jurassic foraminifera: U.S. Geol. Surv. Prof. Paper 236-B, p. 21.

1957. New Cretaceous index foraminifera from northern Alaska: U.S. Nat. Mus. Bull., v. 215, p. 201. 


\section{PLATE 1}

Figures 1-4 Bathysiphon sp., C 29935-29938.

Sample 261-31, CC.

1. $\times 25$;

2-4. $\times 50$.

4. Apertural view showing inclusions of other and slender specimens of Hyperammina (Kalamopsis?, Bathysiphon?) in the tube.

Figures 5-30, Hyperammina gaultina Dam., C 29939-29964, 35,36 29969-29970.

5-18. Sample 261-31, CC.

$5,8-10,12,14,17 . \times 50$.

$6,7,13 . \times 25$

$11,15,16,18 . \times 100$.

12 , 13. Slender specimens clearly showing constrictions of the test.

18. Apertural view showing inclusions of other and slender specimens of Hyperammina (Kalamopsis?) in the tube.

19-25. Sample 261-32, CC, $\times 50$.

26-30, 35, 36. Sample 259-32, CC, $\times 50$.

Figures 31-34 Kalamopsis grzybowskii (Dylazanka)., C2996529968. Sample 259-32, CC, $\times 50$ 


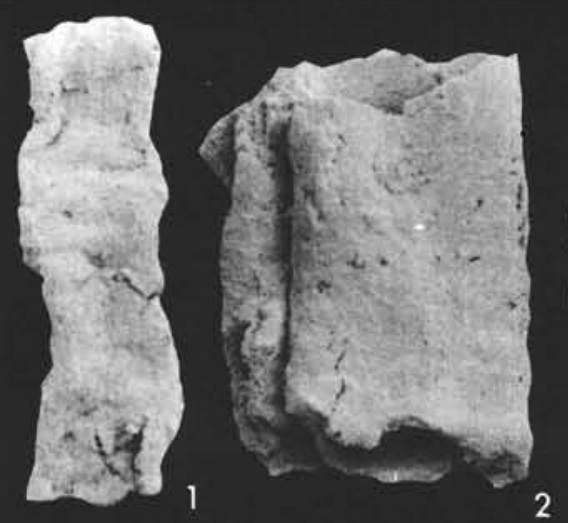

PLATE 1
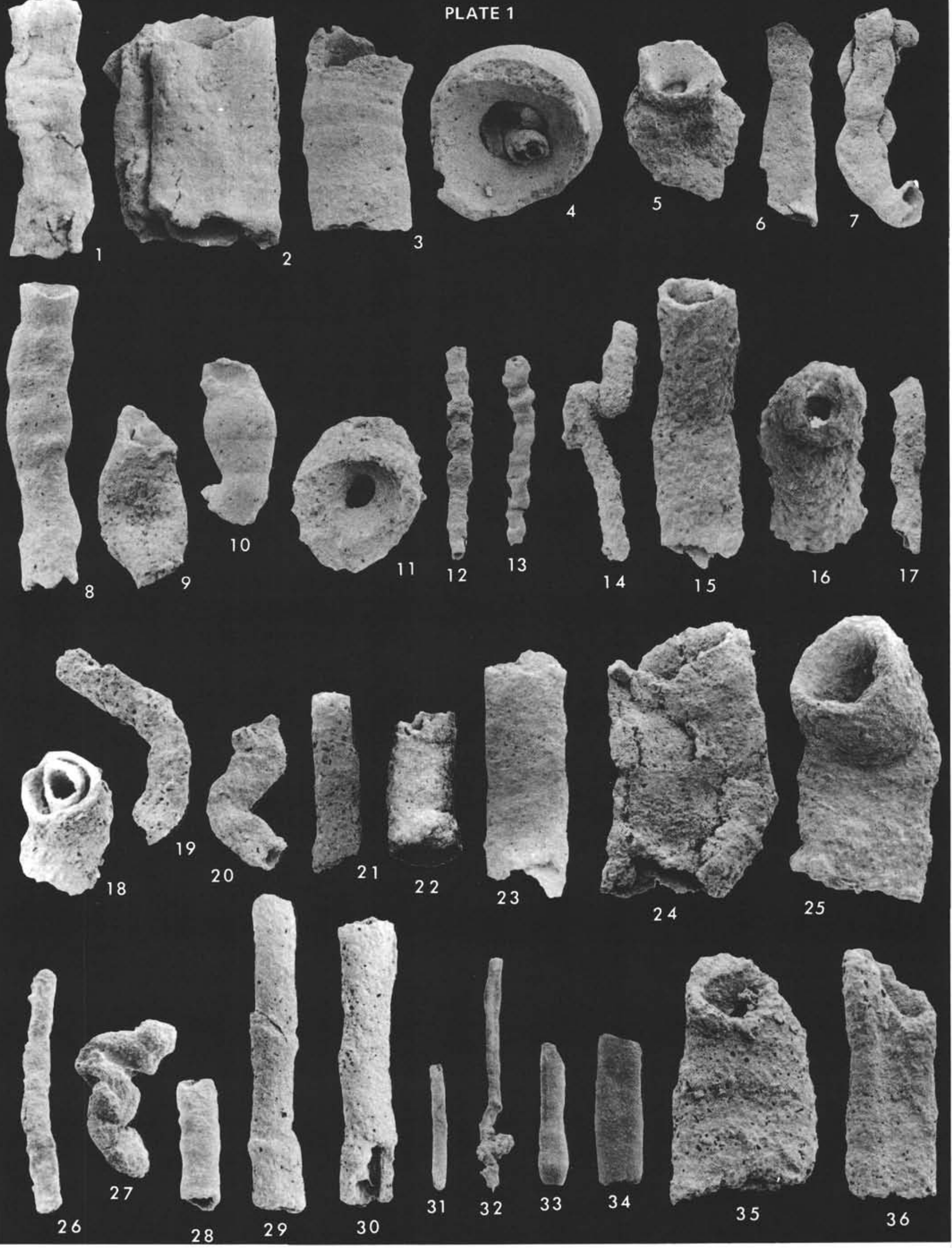
PLATE 2

Figures 1-4 Hyperammina gaultina Dam., C29971-29974.

Sample 259-32, CC.

$1-3 . \times 50$.

4. $\times 25$.

2. Aperturalview showing inclusions of other and slender specimens of Hyperammina (Kalamopsis?) in the tube.

Figures 5-14 Hyperammina sp. 1., C 29975-29984.

Sample 261-31, CC.

$5-8,10-14 . \times 50$.

9. $\times 100$.

Figures 15-22 Hyperammina sp. 2., C 29985-29992.

15-17. Sample 261-30, CC, $\times 50$.

18-22. Sample 261-31, CC, $\times 100$.

Figures 23-26 Hippocrepina depressa Vasicek., C 29993-29996.

Sample 261-32, CC, $\times 50$.

Figures 27-35 Kalamopsis grzybowskii (Dylazanka)., C 2999730005.

Sample 261-32, CC.

$27-31,35 . \times 50$;

32-34. $\times 25$.

Figures 36, 37 Proteonina sp., C 30006-30007, Sample 259-32, CC, $\times 50$.

Figures 38-40 Lituotuba ? sp., C 30008-30010.

Sample 261-32, CC, $\times 50$.

Figures 41-44 Glomospira irregularis (Grzybowski)., C 3001130014.

Sample 261-32, CC.

41. $\times 100$.

42-44. $\times 50$.

Figures 45-50 Glomospira charoides (Jones and Parker)., C 30015-30020.

Sample 261-31, CC, $\times 100$.

Figures 51-54 Glomospira gordialis (Jones and Parker), C 3002130024.

Sample 261-31, CC, $\times 100$. 


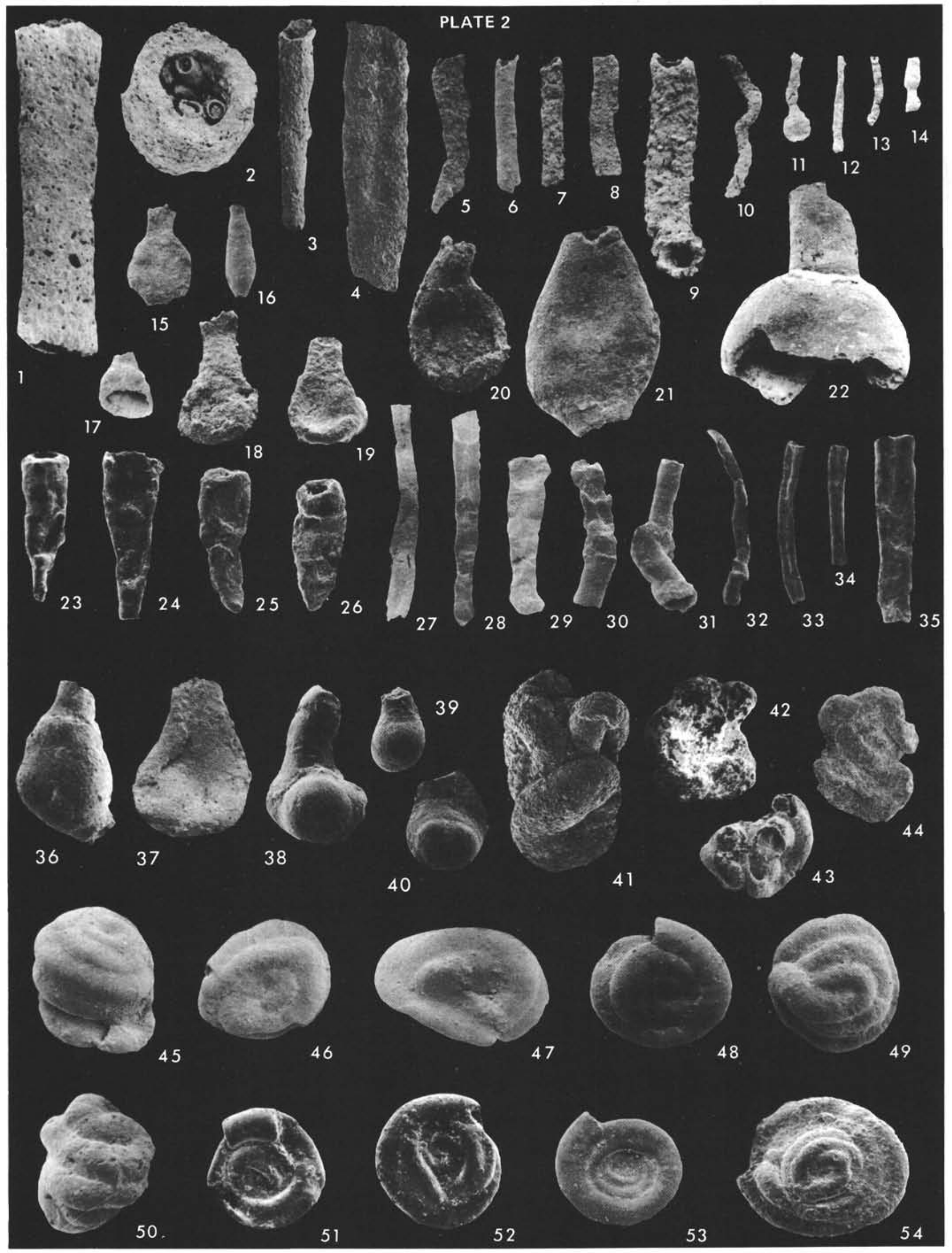




\section{PLATE 3}

Figures 1-3 Glomospira gordialis (Jones and Parker)., C 3002530027.

Sample 261-32, CC, $\times 100$.

Figures 4-6 Glomospira sp., C 30028-30030.

Sample 261-31, CC.

4. $\times 33$.

5. $\times 100$.

5a. $\times 130$.

6. $\times 115$.

5a. Same specimen as in Figure 5 showing details of the grain material in the wall.

Figures 7-13 Ammodiscus tenuissimus (Guembel), C 3003130037.

Sample 261-32, CC, $\times 100$.

Figures 14-17 Ammodiscus incertus (Orbigny)., C 30038-30041.

14, 15. Sample 259-32, CC.

14. $\times 100$.

15. $\times 50$.

16. Sample $259-26-2,42-44 \mathrm{~cm} ; \times 50$.

17. Sample $259-25-2,26-28 \mathrm{~cm} ; \times 50$.

Figure 18 Sorosphaera confusa Brady., C 30042.

Sample 261-32, CC, $\times 50$.

Figure 19 Glomospira irregularis (Grzybowski),, C 30012.

Sample 261-32, CC, $\times 100$.

Same specimen as in Plate 2, Figure 42, showing details of the agglutinated wall. 


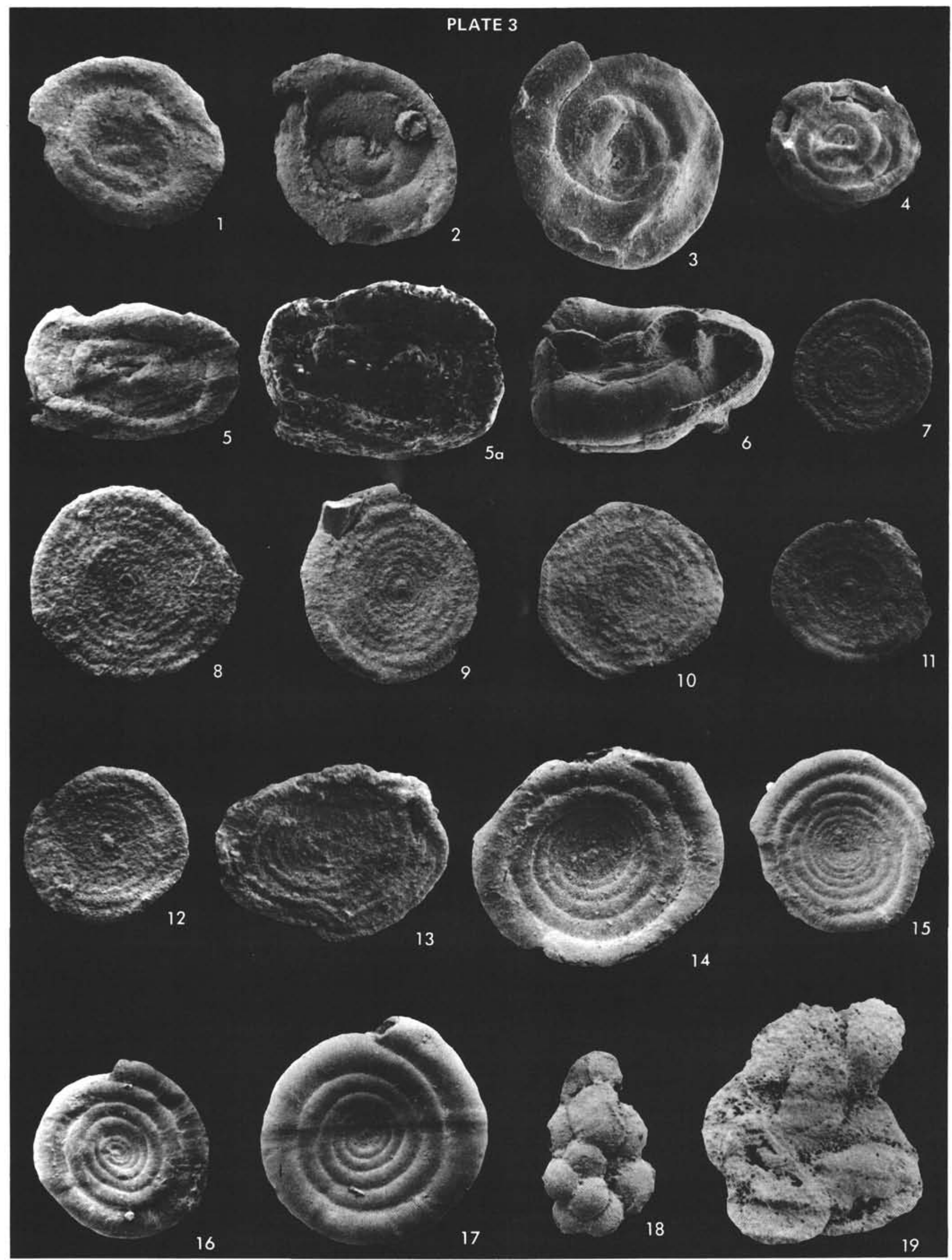

